\title{
When Immigration Becomes a Necessity. ROC Immigration Policy - Lessons for Europe ${ }^{1}$
}

Since 2015, migration phenomenon has been at the forefront of international discussions. In the European Union, the discussions were particularly intense in the wake of the migration crisis which culminated in 2015. In the United Nations, they were sparked by increased migratory movements triggered by the crises in Myanmar/Burma, Yemen, South Sudan, the Central African Republic or Venezuela. In all these discussions, migration has been seen from the perspective of both human rights and the interests of individual states. The latter seem to have prevailed, leading to a kind of offensive against admittance of third-country nationals. Restrictive regulations introduced into national legislations, combined with reluctance towards international legal initiatives promoting concerted efforts to assist and protect migrants and eliminate the underlying causes of migrations, have resulted in adoption of zero-tolerance immigration policies. The pattern has been well visible in most EU member states since 2015.

On this background, the immigration policy of the Republic of China on Taiwan (hereinafter: ROC) stands out. Although the country has not been affected by mass migrations, it has significantly reformed its approach in this regard. As early as the late 1980s ROC realized that its labor shortages could not be compensated for by internal migration. In 2015, the ROC government reported that from 2016 onwards, the working age population would gradually decrease to eventually reach 9 million in 2060, as little as 50 percent of Taiwan's total population. This forecast highlighted the need for immigration policy reforms. The authorities concluded that a change in the current immigration policy would help address the demographic, social and economic challenges faced by Taiwan's ageing population.

The purpose of this paper is to evaluate the current ROC immigration policy and to analyses the relevance and efficiency of the proposed reforms. The analysis uses methods commonly used in social studies in general, and legal and political studies in particular. While legal analysis and systems analysis are the key research methods, comparative analysis has also been applied. The combination of these methods makes it possible to assess the legal solutions constituting Taiwan's immigration policy, as well as to illustrate the legal and institutional changes that have taken place in the country's approach to immigration since the late 1980s.

1 The paper presents the findings of a study funded through a contract between Adam Mickiewicz University in Poznań and the International Relations Department of the Ministry of Education of Taiwan (contract No. 9/2017/dnipk/uam). 


\section{The case for changing the current approach to immigration}

Labor shortages in the range of 200,000 were reported as early as 1989 (Selya, 1992, p. 791). The figure was too high to be compensated for by internal migration. However, the country lacked legislation regulating the employment of foreign workers. Moreover, from 1987 onwards, the number of illegal immigrants began to grow. Most of them were people who officially entered Taiwan as tourists and then took up employment without permission. The purpose of their stay in the ROC was different than declared. Until 1987, the number of such foreigners, mostly coming from the Philippines, Thailand and Malaysia, was estimated at 70,000 (Liu, 1996, p. 605). In 1990, official government figures reported 40,000 illegal immigrants, although unofficial sources estimated the number at 200,000 (ibid.).

Taking labor shortages into consideration (particularly problematic in the context of the objectives of the Six-Year National Development Plan) and growing number of illegal immigrants, in 1990 the country decided to permit employment of foreigners (if single and aged 21 or above) in construction projects related to the Six-Year National Development Plan. Importantly, a number of other conditions had to be met as well: the employer had to demonstrate that they had been unable to find domestic workers for the position, to ensure separate housing for the foreign workers and pay a deposit for each person hired to guarantee that they would leave Taiwan when employment ends. The new regulations did not reduce illegal immigration, mainly because they only admitted foreigners to employment in the construction industry. In addition, the status of foreign workers was not legally regulated, which exposed foreigners to possible exploitation by employers.

Subsequent governmental initiatives aimed at legitimizing the presence of illegal immigrants. In 1991, a tax amnesty program was announced for foreigners in exchange for voluntary deportation to their countries of origin. It is estimated that the prospects of permission to re-enter and legally stay in the ROC encouraged some 22,500 people to reveal (ibid., p. 612).

Continued labor shortages, causing delays in major infrastructure projects (including the construction of a high-speed railway in Taipei), prompted the government to seek workforce in the Philippines, Indonesia, Malaysia and Thailand. To this end, on May 8, 1992, the Employment Service Act was passed. While the law primarily regulated the employment of domestic workers, it also set out the conditions for the employment of foreigners, mainly blue-collar workers. ${ }^{2}$ The Act had two objectives: to solve the problem of labor shortages and to prevent social problems that could be caused by the presence of foreigners in the homogeneous society of the ROC. The new law allowed the employment of foreigners in enterprises that played a key role in the economic development of the country. Importantly, such workers were not defined as immigrants but as guests. Their stay in the Republic of China was by definition temporary (one year, with possible extension for another year with consent of the state) and

2 The Employment Service Act also made it possible to employ foreigners as white-collar workers. They could be employed for two years with possible extension for another year. Unlike bluecollar workers, white-collar workers were not subject to restrictions: they could change employers and were allowed to live in Taiwan with their spouse and children. 
was governed by a contract concluded with a specific employer. Loss of employment was equivalent to an obligation to leave Taiwan. Similarly, marrying a Taiwanese national led to immediate removal from the ROC. It may be seen as a system that was created independently of the immigration policy in order to open up the labor market and reduce labor shortages, whilst maintaining the ethnic and cultural homogeneity of the country (Tseng, Wang, 2011, p. 4). Soon, the guestworkers system was extended to include nursing and care services, thus allowing foreigners to work as carers for the elderly, disabled or children and as domestic helpers. Consequently, the number of foreigners employed in the Republic of China began to grow exponentially (see Chart No. 1 and 2).

\section{Chart 1. Foreign workers in productive industries and social welfare in Taiwan}

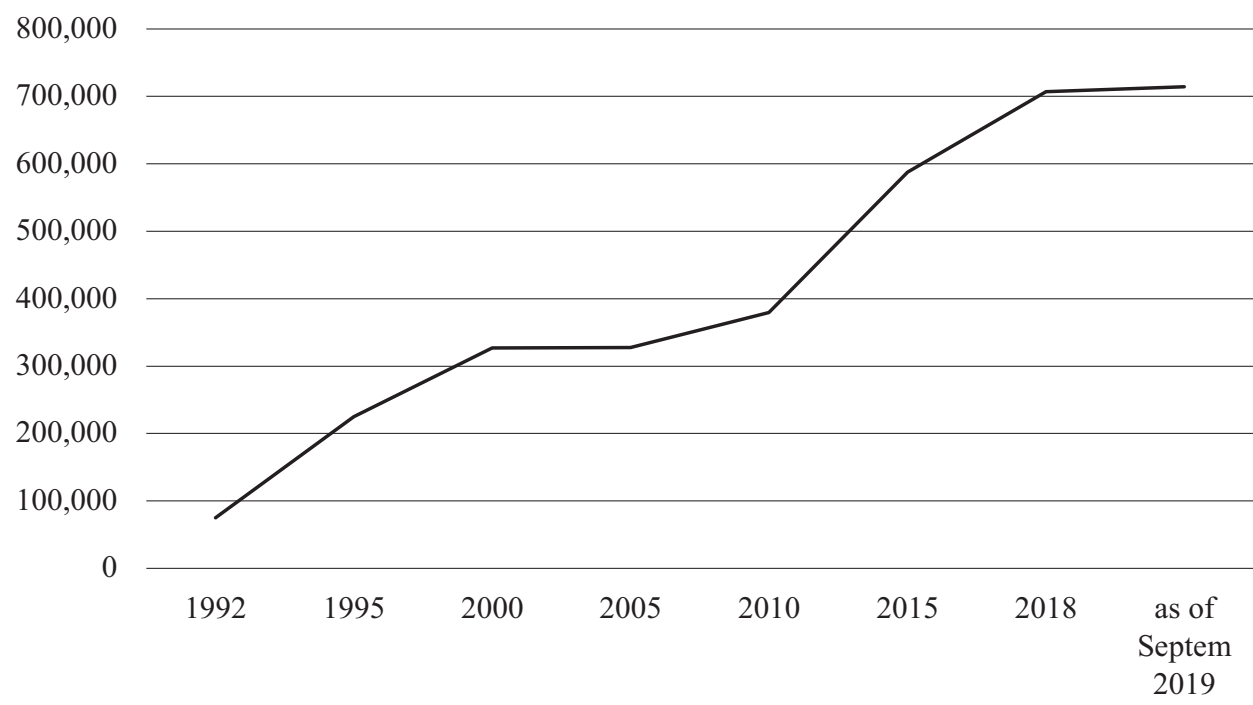

Source: Data from the Ministry of Labor of the Republic of China (Taiwan), http://statdb.mol.gov.tw/html/ mon/c12010.htm, 3.10.2019.

Labor shortages, mainly affecting manufacturing, construction and nursing eventually led to the implementation of the guestworkers system. The underlying causes of those shortages invariably include human capital flight from the ROC on the one hand, and population ageing on the other (see Chart 3). A high rate of emigration has been observed among young people seeking education and then employment mainly in the United States, Canada, Australia and Japan (Hsiao, 2017). The People's Republic of China is another popular destination. Before 1990, the largest group of Taiwanese emigrants were university students who decided to stay in the United States after graduation. According to the Global Talent 2021 report, this year Taiwan will have a record low talent supply and demand ratio at -1.5 (Global Talent, 2012, p. 21). Even though the government has launched the Four Directions and Eights Strategies plan aimed at improving study and employment conditions, granting financial support to academics and researchers, and supporting business in motivating their top employees (Ferry, 2018), openness to immigration is key in sustaining the country's economic develop- 
Chart 2. Foreign workers in Taiwan by industry

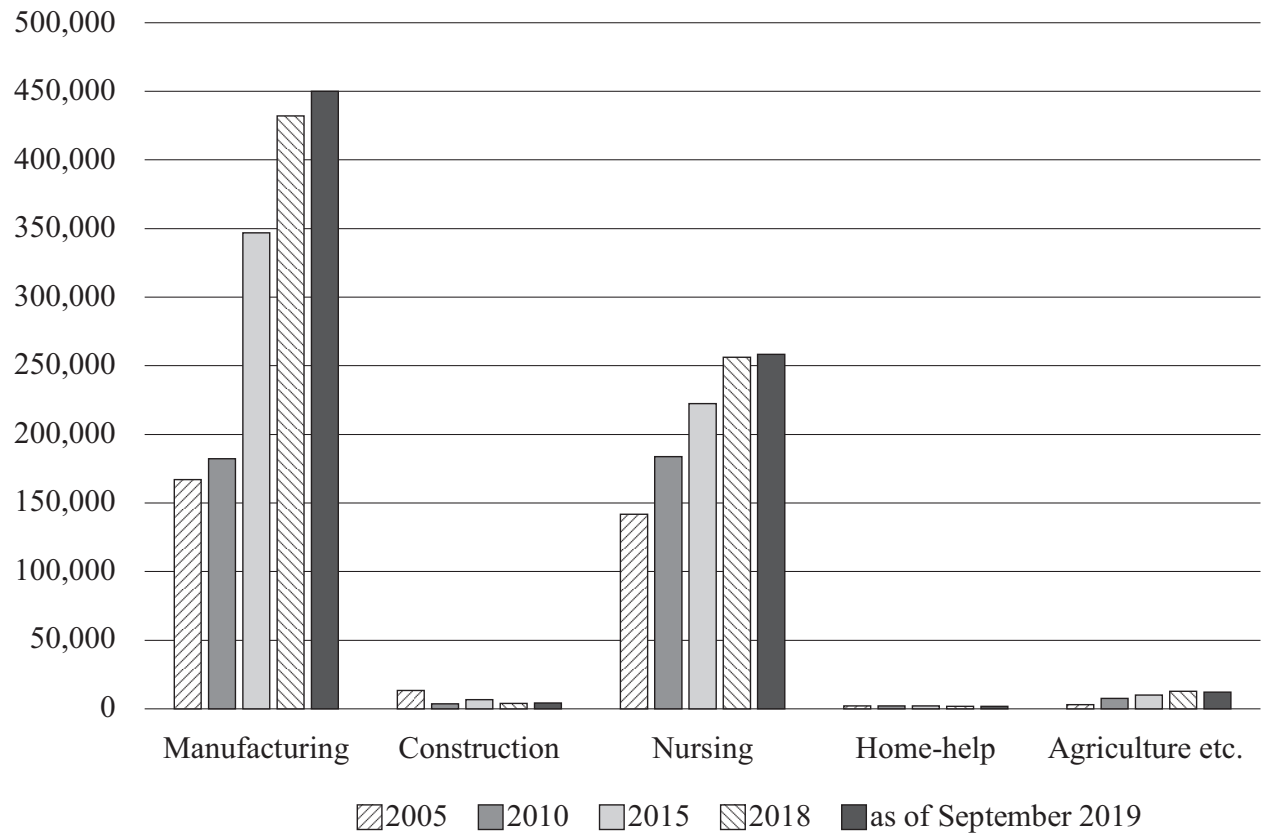

Source: Data from the Ministry of Labor of the Republic of China (Taiwan), http://statdb.mol.gov.tw/html/ mon/c12020.htm, 3.10.2019.

\section{Chart 3. Changes in Taiwan's working age population (in millions)}

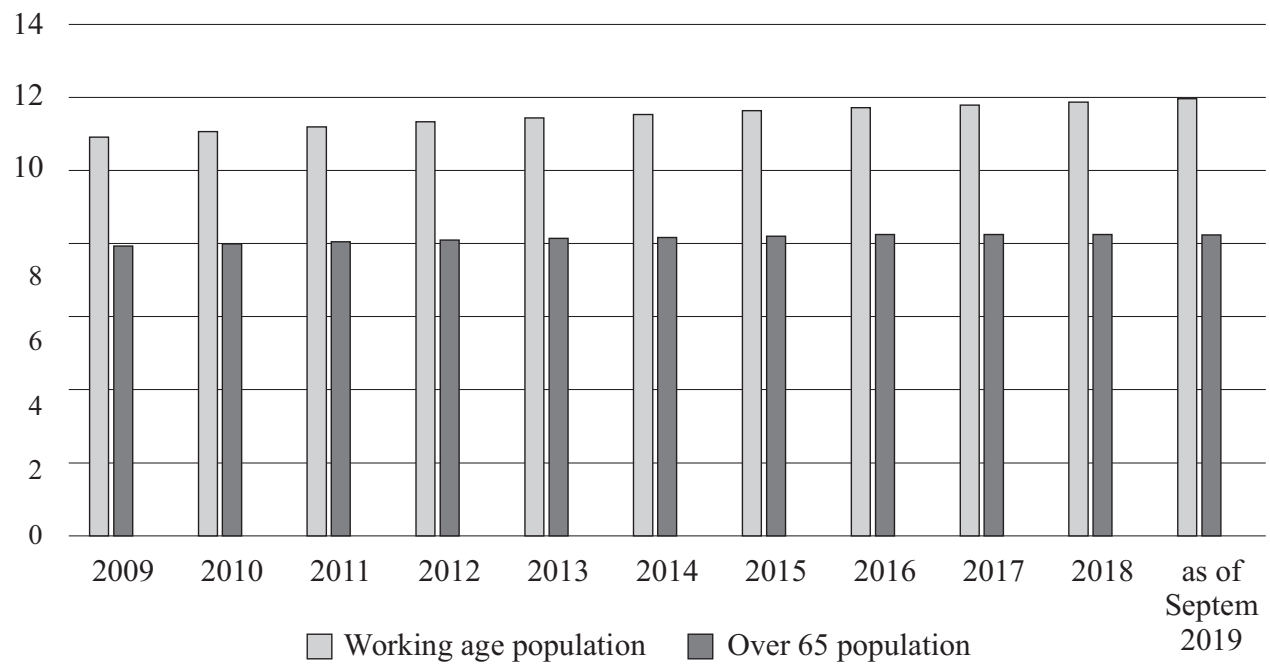

Source: Data from the Statistical Bureau of the Republic of China (Taiwan), National Statistics, https:// eng.stat.gov.tw/lp.asp?ctNode $=1608 \&$ CtUnit $=758 \&$ BaseDSD $=7,3.10 .2019$.

ment. This is even more so given that Taiwan is one of the world's fastest ageing societies. In 2019, the average Taiwanese national was 40.3 years old, which means that a 
half of the population is in their forties or older. In 2025, the ROC will reach the status of a 'super-aged society.' Forecasts show that in 2060 the working age population will represent only 50 percent of the total population, with 42 percent of all people being over 65. Another problem is the country's low fertility rate. While the United Nations studies consider a rate of 1.3 to be 'very low', the ROC's rate was 1.05 in 2010 and 1.11 in $2019^{3}$ (World Population, 2019). A revision of the country's immigration policy has become absolutely necessary.

\section{Trends of changes of Taiwan's immigration policy}

As indicated above, the 1992 reform allowed only for temporary immigration strictly linked to the demand for immigrant workforce. Back in 1987, the Executive Yuan established the Commission of Labor Affairs (CLA), a body dealing with matters involving employment of foreigners, among other issues. Its task was to develop regulatory solutions defining the conditions of employment of foreigners, including the rights and obligations of migrant workers and their employers. On the basis of the Employment Service Act (see above), foreign workers were recruited mainly in less developed countries, from among people with a low socio-economic status (Lin, 2012). Hence, most of them were blue-collar workers from Southeast Asia. The 1992 legislation did not adequately regulate their rights. Although employment contracts formally specified "the length of the contract, the working hours, pay, vacations, insurance, etc." ( $\mathrm{Li}, 2011$, p. 145), in practice the wages paid to foreigners were lower than agreed and overtime work was not uncommon. Foreign workers were housed in tent camps. The regulations also allowed employers to require foreign workers to register every time they wanted to leave the camp at night (Liu, 1996, p. 622). Foreigners were not allowed to change the employer and any change of employment or even changes in working conditions had to be initiated by the employer or a brokerage agency.

In the wake of persistent labor shortages and frequent violations of the fundamental rights of foreigners, the issues omitted from the Employment Service Act were eventually addressed, with particular emphasis on the protection of human rights. On May 21, 1999, the Immigration Act was passed "to unify entry and exit control, safeguard national security, protect human rights, regulate immigration matters, and implement immigration guidance" (Immigration Act, 1999, Art. 1). The Act, most recently amended in November 2016, defines the conditions for entry and stay in the territory of the ROC. It also stipulates the conditions for deportation and for entry refusals. The right of entry will not be granted to foreigners who do not have a valid passport or refuse to produce it, or who use a forged or invalid passport or visa. The right of entry will also be refused to a foreigner who:

- "has made a false statement or hidden important facts about his/her purposes to apply for entry [...].

- Has carried contraband.

3 The fertility rate for 2015-2020 was estimated at 1.15 (World Population, 2019). For comparison: the fertility rates in 1990 and 2000 were 1.77 and 1.67 , respectively. 
- Has a criminal record [...].

- Has suffered from a contagious disease, a mental disease, or other diseases thy may jeopardize public health or social peace.

- Is believed, on the basis of sufficient factual proof, to be incapable of making a living [...]" (Art. 18).

A foreigner will also be denied entry if he/she uses a tourist visa, but does not have a return-trip ticket or a ticket to the final destination, or does not have a visa allowing entry to the final destination. Entry will also be denied to anyone who has been previously deported from the ROC or ordered to leave the country during an earlier stay, or who has previously worked illegally or overstayed. Entry is not allowed for a persons suspected of terrorism, or posing a threat to national interests, public security or decency (ibid.). On a reciprocity basis, the right of entry may be refused to nationals of countries that do not admit ROC nationals for reasons other than mentioned above.

A foreigner who has been allowed to enter may apply for an Alien Resident Certificate (ARC) which entitles to stay in the ROC for a maximum (although renewable) period of three years. If a foreigner resides in the ROC legally and continuously for five years (and for a minimum of 184 days in each year), ${ }^{4}$ he/she may apply for permanent residence and obtain an Alien Permanent Resident Certificate (APRC) if the following conditions are met:

- "is at the age of 20 or over;

- has a decent character;

- has considerable property, skills or talents than enables him/her to make a living on his/her own;

- is beneficial to the national interests of ROC" (Immigration Act, 1999, Art. 25).

Residence permits will be denied for the same reasons as the right of entry. Once issued, the ARC may be revoked if the foreign national: "(1) has submitted false or untruthful information for his/her application; (2) has used illegally acquired, counterfeited, or altered documents," or if he/she has been sentenced to imprisonment for one year or more or has been deported (ibid., Art. 32). The APRC will be revoked in the same cases (see Art. 33) and additionally when the foreigner's stay in the ROC was less than 183 days per year. An Alien Resident Certificate automatically expires if a foreigner has acquired ROC citizenship or an Alien Permanent Resident Certificate. The permanent residence expires once a foreigner has acquired the citizenship of the Republic of China.

In keeping with the principle of territorial jurisdiction, a foreigner may be forbidden to leave the ROC on request of a judicial, fiscal, or any other competent authority investigating an offence (ibid., Art. 21). The ROC legislation provides for the deportation of foreign nationals in situations recognized by the legislation of other countries, i.e.: illegal entry, undertaking employment or another activity that is incompatible with the purpose of the visit or stay, overstaying, committing an offence in the territory of the Republic of China (as long as competent law enforcement or judicial authori-

${ }^{4}$ These periods do not include the period of staying (residing) in ROC by a foreigner whose residence in the Taiwan Area is permitted due to studies or employment in marine fishing/netting; householding and nursing; or employment in response to national major construction projects or economic/social development needs (Employment, 2018, Art. 46, subparas. 8-10). 
ties have not demanded deportation to be suspended in order to bring the offender to justice), as well as in the circumstances justifying refusal of entry. A unique solution provided for in the ROC legislation is the deportation of a foreign worker who has left "the designated overnight lodging facility without permission" (ibid., Art. 36(3)). An individual concerned is given 10 days to leave the Republic. If he/she does not comply, competent state authorities will proceed with forced deportation. The affected foreigner has the right to provide testimony, based on which the deportation decision may be overruled. The case will then be examined by a review committee, consisting of representatives of "relevant agencies, public figures for social justice, scholars and experts" (ibid., Art. 36). Experts should represent at least 50 percent of the committee's line-up. Deportation without a review procedure is possible if the person concerned has waived in writing his/her right of appeal, has agreed to leave the ROC voluntarily, has been found guilty of terrorism or endangering national interests, public safety and public order, or if the deportation is ordered pursuant to a final judgment.

In an effort to sustain the country's economic growth by encouraging potential immigrants, the Talent Recruitment Policy Committee was established "to explore ways to attract both white-collar professionals and specialized blue-collar skilled foreigners" (Ferry, 2015). Made up of representatives of various ministries, including Labor, Economy, Education and Health, the Committee identifies the changes necessary to liberalize the immigration policy. The goal is to encourage migrant workers with a higher social status, who are better educated and come from developed countries. This approach is generally accepted by the public. An online survey in November 2018 showed that 76 percent of the respondents were in favor of allowing immigration only for qualified foreigners, whereas 29.8 percent supported immigration for everyone, regardless of their qualifications and nationality (Rich, 2019). A similar view was expressed by the government in the Act for the Recruitment and Employment of Foreign Professionals passed on November 22, 2017. The Act defines three categories of individuals: senior professionals, special professionals and professionals. The first category includes foreign senior professionals whose work is in particular demand in the ROC and who have special skills in science, research, industry or commerce. In their turn, foreign special professionals are those with "special expertise needed by the State in science \& technology, the economy, education, culture, the arts, sports and other fields" (Act, 2017, Art. 4.2). Hence, this category includes, academics, winners of reputable international awards, persons recommended by recognized public associations or with established international reputation, as well as persons with senior executive experience. The third category ('Professionals') consists of such groups as freelance artists (for whom the ROC labor market had never been open before) and public school teachers. The most important solutions include relaxed visa requirements (also for family members) and less restrictive regulations on employment, stay and residence permits. The maximum period for which permits are issued was extended from three to five years, with possible renewal at the employer's request (Art. 7). The Employment Gold Card is an entirely new solution. It is a combination of a resident visa, a work permit, a resident certificate and a re-entry permit. It can be applied for by foreign special professionals. The Gold Card is valid for one to three years and can be renewed (Art. 8). The 2017 Act also introduced health and pension insurance guaran- 
tees. The former are also available for family members of foreigners who have worked in Taiwan for a full six months. Pension insurance was extended to include permanent residence permit holders (Art. 11).

Amendments were also introduced to the Employment Service Act, most recently in November 2018. They liberalize the earlier approach to long-term immigration involving residence and employment in the Republic of China. While domestic recruitment is still a priority (Employment, 2018, Art. 47), the time period available for foreigners to find new employment after termination of the original one (i.e. the one indicated in the visa application) was extended from 90 days to six months. Only after this period (and unless a new employment contract has been concluded) is the individual concerned obliged to leave Taiwan. In an effort to encourage foreign students graduating from Taiwanese universities to stay and work in the ROC, the previously required two-year work experience is no longer obligatory. The procedure for obtaining an Alien Permanent Resident Certificate was simplified as well: a face-to-face interview is no longer necessary and the number of documents required was reduced. Regulations applicable to foreign workers' children were also relaxed: the period of their residence in the ROC with their parents now counts towards the minimum period necessary to obtain an APRC.

While labor immigration remains a major legislative concern for the Republic of China, the country has made efforts to introduce complex solutions covering various aspects of migration. This is why the Immigration Act also addresses international human trafficking, aiming to prevent and penalize it and to protect its victims. Dedicated officers operate as part of prosecutor's offices that are in charge of prosecuting human trafficking cases. Investigations are carried out by task forces operating as part of law enforcement services. Hotlines between police and employment agencies are in place to enable instant exchange of information on human trafficking. Victims are granted psychological and legal support and have access to an interpreter. They are also offered accommodation that meets their personal needs. The presence of a social worker during interrogations and investigative activities and in court is also ensured. For the duration of the proceedings, foreign victims of human trafficking obtain a Temporary Visit Permit. The document is issued for a period up to six months, but can be extended if the investigation takes longer than that. Victims are also granted a work permit and are not subject to the restrictions under the Employment Service Act (Immigration Act, 1999, Art. 44). As soon as the proceedings in a human trafficking case are concluded, the victim is sent back to the country of origin. The Human Trafficking Prevention Act contains a detailed definition of penalties faced by persons involved in human trafficking. These include fines of up to five million New Taiwan Dollars (roughly equivalent to USD 163,000) or up to seven years' imprisonment (Human Trafficking, 2009, Arts. 32 and 33). Such penalties may be imposed on anyone who makes another person work without adequate remuneration using "force, threat, intimidation, confinement, monitoring, drugs, fraud, hypnosis." (ibid.). Similarly, the penalties are faced by anyone found guilty of "recruiting, transporting, delivering, receiving, harboring, hiding, brokering, or accommodating" another person under 18 years of age in order to subject $\mathrm{him} /$ her to labor exploitation or underpayment for profit (ibid.). The ROC's efforts to eradicate international human trafficking are also manifested in the memoranda of understanding and cooperation agreements signed with 17 countries. 
The migration policy reforms introduced since the late 1990s have aimed at sustaining the country's economic growth and stabilizing the labor market on the one hand, and at protecting the fundamental rights of migrants and eliminating serious violations of these rights on the other hand. The reforms have reshaped the ROC's migration policy. If seen purely from the perspective of the legal framework, the ROC is clearly one of the immigration-friendly countries. Importantly, however, the ROC considers immigration as an opportunity to foster its economic growth, but not so its social or cultural development. To protect the homogeneity of society, the guestworkers system maintains the temporary nature of economic immigration, and efforts are taken to recruit workers for specific sectors of the economy only, primarily from ASEAN member states. Consequently, there are no legislative or institutional solutions aimed at the integration of foreigners into the host society.

Moreover, the migration practice in the ROC often diverges from the regulatory framework. The Republic's authorities have been criticized for their insufficient efforts to combat exploitation and inhumane working conditions suffered by migrants, and even accused of ignoring the rights of migrants. Until the adoption of the Act for the Recruitment and Employment of Foreign Professionals in 2017, migrants were excluded from the social security system. Currently, workers' rights violations have become a serious issue and are particularly notorious among two groups of foreign workers. The first of those groups are migrant fishermen, who have been repeatedly mentioned in the annual reports of the US Department of State. Their case was also raised by NGOs during the 2018 International Workshop on Strategies for Combating Human Trafficking held in the ROC in July 2018. There seems to be "separation of purview between the Ministry of Labor (MOL) and the Fisheries Agency (FA), coupled with insufficient inspection protocols, continued to impede efforts to address forced labor on Taiwan-flagged and -owed fishing vessels in the highly vulnerable Distant Water Fleet" (Trafficking, 2019, p. 45). The other group are migrant domestic workers (MDWs), including carers, nurses and housemaids, mainly from the Philippines and Indonesia. Since 2001, "eligibility for hiring foreign domestic workers in Taiwan has been determined by a need-based point system" and applications are subjected to review (Wang, Chung et al., 2018). ${ }^{5}$ However, this is essentially where the state control over the practice of hiring MDWs ends, which frequently leads to abuse, such as low wages, extended working hours and poor working conditions. ${ }^{6}$ Although the ROC authorities originally decided to cover MDWs with the assurances under the Labor Standards Act of April 1, 1998, the Ministry of Labor eventually "excluded domestic workers from the scope of the Labor Standards Act" (ibid.). As a result, these individuals "are not regarded as workers but as temporary caregivers," which is

${ }^{5}$ Hiring of foreigners for family care work is prohibited - possible only when the care-receiving person is determined through "professional evaluation conducted by medical institution through team method" as requiring 24-h care because of having "especially grave physical or mental diseases" (as cited by Hoang, 2017, p. 5).

${ }^{6}$ Since most domestic workers are women, they are sometimes referred to as 'global Cinderellas'- see Lan (2006). 
why labor inspectors hardly ever run checks on private individuals employing migrant domestic workers (Laliberté, 2017, pp. 124-125). In 2018 MDWs organized protests, demanding coverage under the Labor Standards Act and complaining about being unable to exercise their right to have a weekly day off. Migrants employed as domestic helpers, or carers of children, elderly or disabled people also expect the broker system to be replaced by direct hiring, which has been promoted since 2006 .

$$
* * *
$$

Exercising its sovereign powers, each state has the right to lay down general rules of entry and stay of third-country nationals and stateless persons. It has the right to refuse entry and to remove a third-country national or stateless person from its territory at any time, in accordance with domestic regulations. These principles form the basis of migration and visa policies, the purpose of which is to pursue the interests of a sovereign state, taking into account political, social and economic considerations. For the Republic of China, immigration has become an essential tool in sustaining its economic development and ensuring the stability of the pension system. Changes to the migration regulations reflect the pursuit of these objectives. However, a robust immigration policy takes more than just regulating the rules of entry and stay in the ROC. Simple contractual regulations resulting from bilateral international agreements need to be replaced with a comprehensive legislative framework covering the rights of all migrants working in Taiwan. Can the ROC approach be a lesson for Europe, and particularly for the EU member states? Yes, as long as immigration is seen as an opportunity for securing economic growth and avoiding the likely problems with social security systems, but less so when it comes to perceiving immigration as a threat to social unity and linguistic, religious and cultural homogeneity. Importantly, such a perception of immigration is common to Taiwan and Central and Eastern European countries, as well as Austria. In debates on possible ways of solving the migration problem, all these countries speak openly about threats to state and public security, as well as threats to cultural and religious identity (see also: Potyrała, 2019, pp. 97-115). Such threats are directly caused by "a change in the ethnic, cultural, religious or linguistic composition of the population [...] If the influx is too large, it will threaten the society's ability to sustain itself the way it has thus far" (Buzan, 1991, p. 447). All these potential threats must be taken into account in migration, visa and border protection policies, as well as in laws regulating the operation of agencies combating organized crime. Undoubtedly however, these threats are sometimes overestimated and an accurate assessment of their actual impact is often difficult. Threats, whether actually existing or potential, are not continuous, only exist in a certain context, may become more intensive or may not materialize at all.

\section{Bibliography}

Act for the Recruitment and Employment of Foreign Professionals (2017), 22.11.2017, Presidential Order No. 10600140481, the Executive Yuan Order No. 1070002554. 
Buzan Barry (1991), New Patterns of Global Security in the Twenty-First Century, "International Affairs", vol. 67, no. 3.

Employment Service Act (1992), 5.05.1992, Presidential Order No. 2359, as amended.

Fell Dafydd (2014), Migration through the lens of political advertising: how Taiwanese parties discuss migration, in: Migration to and from Taiwan, eds. Ch. Kuei-fen, D. Fell, L. Ping, London-New York.

Ferreted Foreign Illegal Residents (2019), National Immigration Agency, MOI, https://www.moi.gov. tw/files/site_stuff/321/1/month/month_en.html\#6\%20Immigration\%20Adm 10.05.2019.

Ferry Timothy (2015), Rethinking Taiwan's Immigration Policy, "Taiwan Business Topics", 16.04.2015, https://topics.amcham.com.tw/2015/04/rethinking-taiwans-immigration-policy/, 17.05.2019.

Ferry Timothy (2018), Taiwan Competes for Talent and Manpower, "Taiwan Business Topics", 18.04.2018, https://topics.amcham.com.tw/2018/04/taiwan-competes-for-talent-and-manpower/, 17.05.2019.

Foreign population in Taiwan hits record high (2012), "Taiwan Today", 6.02.2012, https://taiwantoday.tw/news.php?unit=10\&post=19076, 10.05.2019.

Foreign Residents (2019), National Immigration Agency, MOI, https://www.moi.gov.tw/files/site stuff/321/1/month/month_en.html\#6\%20Immigration\%20Adm, 10.05.2019.

Global Talent 2021. How the new geography of talent will transform human resource strategies (2012), Oxford Economics, Oxford.

Hoang Lan Anh (2017), Governmentality in Asian Migration Regimes: the Case of Labour Migration from Vietnam to Taiwan, "Population, Space and Place", vol. 23, DOI: 10.1002/psp.2019.

Hsia Hsiao-Chuan (2008), The Development of Immigrant Movement in Taiwan: the Case of Alliance of Human Rights Legislation for Immigrants and Migrants, "Development and Society", vol. 37 , no. 2.

Hsiao Ting-Fang (2017), 'Farewell, Taiwan'. Taiwan's growing Talent Drain, "CommonWealth Magazine", vol. 628.

Huang Wen-Chih Billy (2018), Immigrant crime in Taiwan: perspectives from Eastern Asia, "Forensic Research \& Criminology International Journal”, vol. 6, Issue 3.

Human Trafficking Prevention Act (2009), 23.01.2009, Presidential Decree No. 09800019281, the Executive Yuan Order No. 0980029315C, as amended.

Immigration Act (1999), 21.05.1999, Presidential Decree No. 8800119740, the Executive Yuan Order No. 20932, as amended.

Kitamura Yumi (2018), Introduction to the Special Issue - Re-positioning China's and Taiwan's Migration in Southeast Asia, "Issues and Studies: A Social Science Quarterly on China, Taiwan, and East Asian Affairs", vol. 54, no. 1.

Kuei-fen Chiu, Fell Dafydd, Ping Lin (2014), Migration to and from Taiwan: identities, politics and belonging, in: Migration to and from Taiwan, eds. Ch. Kuei-fen, D. Fell, L. Ping, LondonNew York.

Laliberté Andre (2017), Responses to Abuse Against Migrant Domestic Workers: A Multi-scalar Comparison of Taiwan, Hong Kong, and Shanghai, in: Gender, Migration, and the Work of Care: A Multi-Scalar Approach to the Pacific Rim, eds. S. Michel, I. Peng, Cham.

Lan Pei-Chia (2006), Global Cinderellas: Migrant Domestics and Newly Rich Employers in Taiwan, Durham-London.

Li William D. H. (2011), Developmental State, Human Rights and Migrant Workers, "Development and Society", vol. 40, no. 1.

Lin Ji-Ping (2018), The Migration of Labor between Taiwan and Southeast Asia: Changing Policies, The National Bureau of Asian Research NBR, January. 
Lin Ji-Ping (2012), Tradition and Progress: Taiwan's Evolving Migration Reality, Migration Policy Institute, 24.01.2012.

Liu Dorothy S. (1996), The 1992 Employment Service Act and the Influx of foreign workers in Taiwan and Translation of the 1994 Implementary Provisions, "Pacific Rim Law \& Policy Journal", vol. 5 , no. 3 .

MyungHee Kim (2016), Lessons from Taiwan's Revised Immigration Law for Marriage Migrants, "International Information Institute", vol. 19, no. 4.

Overstayed Foreign Nationals with Tourist Visas (2019), National Immigration Agency, MOI, https://www.moi.gov.tw/files/site_stuff/321/1/month/month_en.html\#6\%20Immigration\%20Adm, 10.05.2019.

Potyrała Anna (2019), Kryzys migracyjny 2015+ Między solidarnościa a partykularyzmem, Poznań.

Rich Timothy S. (2019), How Taiwanese Think About Immigration, "The Diplomat", 16.01.2019, https://thediplomat.com/2019/01/how-taiwanese-think-about-immigration/, 14.05.2019.

Selya Roger Mark (1992), Illegal Migration in Taiwan: A Preliminary Overview, "The International Migration Review", vol. 26, no. 3.

Song Jiyoung (2015), Redefining Human Security for Vulnerable Migrants in East Asia, "Journal of Human Security", vol. 11, Issue 1.

Trafficking in persons report. June 2019 (2019), United States Department of State, Washington.

Tseng Yen fen, Wang Hong-zen (2011), Governing Migrant Workers at a Distance: Managing the Temporary Status of Guestworkers in Taiwan, "International Migration", vol. 51, Issue 4.

Wang Chieh-Hsuan, Chung Chien-Ping, Hwang Jen-Te, Ning Chia-yang (2018), The Foreign Domestic Workers in Singapore, Hang Kong, and Taiwan: Should Minimum Wage Apply to Foreign Domestic Workers?, "The Chinese Economy", vol. 51, Issue 2, DOI: 10.1080/10971475.2018.1447831.

Wang Hong-zen (2011), Immigration Trends and Policy Changes in Taiwan, "Asian and Pacific Migration Journal", vol. 20, no. 2.

World Population Prospects 2019 (2019), United Nations. Population Division. Department of Economic and Social Affairs, New York.

\section{Summary}

Migration issues have been at the forefront of international discussions since 2015. They have been considered from the perspective of both human rights and the interests of individual states. The latter seem to have prevailed, leading to a kind of offensive against admittance of third-country nationals. Restrictive regulations introduced into national legislations, combined with reluctance towards international legal initiatives promoting concerted efforts to assist and protect migrants and eliminate the underlying causes of migrations, have resulted in adoption of zero-tolerance immigration policies. In this paper, the author sets out to assess the immigration policy of the Republic of China on Taiwan. Having recognized that its labor shortages cannot be compensated for by internal migration, the country has significantly remodeled its approach to immigration. The answer to the question about the relevance and efficiency of the proposed legal solutions will be used to indicate possible solutions for EU Member States planning to reform the common migration and asylum policies. The analysis uses methods commonly applied in social studies in general, and legal and political studies in particular. While legal analysis and systems analysis are the key research methods, comparative analysis has been used as well.

Key words: immigration, immigration policy, opportunities, threats, Republic of China, Taiwan 


\section{Gdy imigracja staje się koniecznością. Polityka imigracyjna Republiki Chińskiej na Tajwanie - lekcje dla Europy}

\section{Streszczenie}

Od 2015 roku naczelne miejsce w dyskusjach toczonych na arenie międzynarodowej zajmują kwestie migracyjne. Rozważane są zarówno przez pryzmat praw człowieka, jak i interesów poszczególnych państw. Te ostatnie zdominowały dyskusje, prowadząc do swoistej ofensywy skierowanej przeciw możliwości przyjmowania obywateli państw trzecich. Restrykcyjne rozwiązania prawne wprowadzane do prawa krajowego, sprzeciw wobec międzynarodowych inicjatyw prawnych, podkreślających konieczność solidarnego działania na rzecz pomocy i ochrony osób migrujących oraz likwidacji przyczyn masowych przemieszczeń ludności, skutkują przyjmowaniem przez poszczególne państwa polityki zerowej imigracji. Celem niniejszego artykułu jest ocena polityki imigracyjnej Republiki Chińskiej na Tajwanie, która dostrzegając niedobory siły roboczej i brak możliwości ich uzupełnienia przy pomocy migracji wewnętrznej, przemodelowała w znaczący sposób podejście do imigracji. Odpowiedź na pytanie o zasadność i skuteczność proponowanych rozwiązań prawnych posłużyć ma do wskazania rozwiązań możliwych do zastosowania przez państwa członkowskie Unii Europejskiej, dyskutujące nad reformą wspólnych polityk: imigracyjnej i azylowej. Rozważania prowadzone będą przy wykorzystaniu metod charakterystycznych dla nauk społecznych, w szczególności nauk prawnych i nauk o polityce. Kluczowe znaczenie przypisano metodzie analizy prawnej i analizy systemowej, zastosowano również metodę porównawczą.

Słowa kluczowe: imigracja, polityka imigracyjna, szanse, zagrożenia, Republika Chińska, Tajwan 
